\title{
The Green Church
}

\author{
Mark L. Gillem, PhD, AIA, AICP
}

University of Oregon, Eugene, Oregon, USA

\begin{abstract}
If "green" is an environmental concept applicable to the design and construction of buildings and landscapes, then we should not limit the scope of the concept solely to the natural environment. Rather, we should include key "environments" in which designers operate, including the socio-cultural, political, and natural environments. In this paper, I present a case study in "green" design that expands the scope of the concept and recognizes the interrelationship between these multiple environments. Using recent construction and renovation on the campus of the First Presbyterian Church of Berkeley as the case, I show how these environments are mutually supportive. Moreover, I argue that if designers simply consider the natural environment, their laudable goals may never be realized. In the first part of the paper, I provide a background on the project and its physical and socio-cultural setting. Second, I discuss how the different "environments" were addressed in the planning and design of the project. I then introduce specific "green" strategies that were employed in the design of the new and renovated buildings. These include considering renovation as the first imperative, thinking holistically about the entire campus, and applying a simplified approach to "greening" the buildings. I conclude by offering suggestions for future designers interested in reducing the environmental impact of their buildings.
\end{abstract}

Keywords: Sustainability, Adaptive Reuse, Human Context

\section{INTRODUCTION}

"That has never happened here before," exclaimed Mark Rhoades, a planner for the City of Berkeley. I pointed upwards and offered, "It must be help from above."

"What do you mean?" he asked.

"Well Mark," I replied. "This is a church project."

"Then it must be a miracle," he concluded.

The "miracle" he was referring to was the unanimous approval in the spring of 2002 by the City of Berkeley's Zoning Adjustment Board of the application by First Presbyterian Church of Berkeley to expand their campus. The Board even approved the project on their consent calendar, which means there was not any discussion about the project - just a vote. The Board could do this because there was no public opposition to the project only support, which is highly unusual in Berkeley. At over \$25 million, with two levels of underground parking, a $3,716 \mathrm{sm}(40,000 \mathrm{sf})$ new building for offices, classrooms, a chapel, and a music room, and renovation of a 819.2 $\mathrm{sm}(8,818 \mathrm{sf})$ historic structure for classrooms and a counselling center, the project was one of the largest proposed in Berkeley at the time. Just two weeks before, at an earlier meeting of the Zoning Adjustment Board, the commissioners spent nearly two hours debating the merits of a proposal for a small restaurant. With that kind of scrutiny given to such a small project, the church was prepared for a lengthy final debate on their application. But the debate was not needed. The church submitted a project that was designed with respect to the needs and desires of the church membership and the larger community. The design also responded to the importance of the socio-cultural, political, and natural environments in which all buildings reside.

Established in Berkeley in 1878, the First Presbyterian Church has grown from a small congregation to what can now be considered a mega-church - a regional church with over 1,800 members. The church supports a wide array of ministries and requires a variety of spaces to meet its mission needs. Rapid growth in the late 1990s spurred thinking about expansion and led to the goal of accommodating 2,500 members. This growth goal led to a long and arduous design process that eventually resulted in the proposal approved by the Zoning Adjustment Board. 


\section{PROJECT BACKGROUND}

\subsection{The First Proposal: A $\$ 300,000$ Lost Design Effort}

In late 1990s, the church hired a design firm to help plan for the needed expansion. The designers coordinated visioning sessions with the congregation, conducted public workshops, and developed alternatives for the church to consider. While this was a textbook example of a participatory process, the outcome was less than ideal. The final design was largely unbuildable. It exceeded the church's budget by $\$ 20$ million. Given the proposed new building's 5-story height ( 3 is allowed in the zone) and excessive lot coverage, it would have required numerous variances from city zoning regulations that would likely not have been approved. It relied on air conditioning and it called for a design that one church member described as a "prison." Over $50 \%$ of the offices did not have windows, internal corridors were narrow and dark, classrooms were all nearly the same size (thus limiting flexibility), the ground floor was cut off from the public realm by fencing that separated child-care play areas from the street, and some of the most public spaces were placed on the floor with the least public access - the fifth floor. As one member of the building committee reported, the focus of the first design team was on aesthetics at the expense of almost every other concern.

From the community's perspective, the project ignored a city-designated historic building on the property. The issue of the historic building was quite sensitive. Several years earlier, the church purchased the run-down McKinley Annex and intended to demolish it to make way for new construction. At the time of the purchase, the three-story wood frame building, which was built in 1906 as a schoolhouse, had several apartments and an activist group of tenants. Given that this was one of the last remaining examples of a shingle-clad schoolhouse in Berkeley (even though it was converted during World War II to housing), the City of Berkeley's Landmark Preservation Commission designated the building a Structure of Merit. The designation came on the eve of demolition, after the city had issued the church a demolition permit. Since the city issued a permit, the church believed they had a right to demolish the building, regardless of the last-minute designation of the building as an historic property. The city thought otherwise. The church sued the city and eventually won on appeal. The city had to pay the church's substantial legal fees and the church could demolish the building if an Environmental Impact Report (EIR) justified demolition. This requirement would be difficult to meet since the EIR process by law required public input and the public was not in the mood to let the church demolish the building. Hence, the designers of the first proposal felt justified in ignoring rather than demolishing the building and its troubled history. Without upgrades, many neighbors of the church knew the building would certainly fall into disrepair and, at some point, deteriorate past the point of saving. As a result of this approach, members of a local preservation group, the Berkeley Architectural Heritage Association, actively opposed the project.

Other neighborhood groups had their own concerns with the first proposal. Members of a local business group, the Telegraph Area Association, did not like the variances the church would need to request. In a way, asking for a variance from a planning regulation is like asking for a special favor. Some neighbors did not want to see a church get special treatment. And a group of University of California graduate planning students, calling themselves Students for a Livable Southside, did not approve of the design's inward focus and its oversized (at least in their minds) parking garage. They also believed that the designers failed to provide adequate public open space on the site. With opposition from these groups, the plan had little chance of approval.

Shortly before the congregation was to vote on the proposed plan, members of the church's building committee decided that it was in fact unbuildable, despite assurances to the contrary by the initial architect. After it became clear that the first design firm was unwilling to modify their proposal, the church abandoned the effort and embarked on a new design. Given that the church spent approximately $\$ 300,000$ with the first firm, this was not an easy decision to make.

\subsection{The Revised Plan: A Campus not a Building}

Fortunately, in the initial planning effort, the church developed a compelling vision for the project. Namely, the church wanted the campus to be "warm, welcoming, and inviting" to its own members and to the larger community. The church also wanted the buildings to represent the best approaches to environmental stewardship while meeting the space needs of the growing congregation. These two goals - compatibility and stewardship became the basis for the revised plan. The focus shifted from the design of one building to the design of an entire campus that could be developed over several phases as funds permitted.

Before developing the revised plan, the new concept design team first reprogrammed the project through a series of workshops and user interviews. The goal was to minimize the need for new construction and prioritize uses in order to develop an approach that did not rely on a five-story new building. Given that three-stories was the maximum allowable height for the zone, anything taller would require special approval from the city, which would be nearly impossible to obtain in Berkeley. Also, by shrinking the required new area, the church's $\$ 25$ million budget would be more attainable. The new concept design team also met with the neighborhood 
opposition to identify their concerns. Historic preservationists wanted the historic building (McKinley Annex) renovated. Local business leaders did not support the church's request for significant variances. The students did not want the large parking garage initially proposed by the church, which accommodated over 250 cars. They felt this would encourage driving over alternative means of transportation. And they wanted the building to be designed in a way that would minimize its environmental impact while providing publicly accessible open space.

In reconsidering the design, the concept design team stressed to the church that the project should respond to these concerns and it should fit within its context while contributing to the larger neighborhood structure. The historic building should be renovated and incorporated into the overall campus design, the height of the new building (Geneva Hall) should not exceed three floors (Fig. 1), a significant publicly accessible plaza should be part of the design, and structured parking should be kept to a minimum. In terms of environmental stewardship, the design should, at a minimum, allow for passive cooling and heating, and abundant natural lighting.

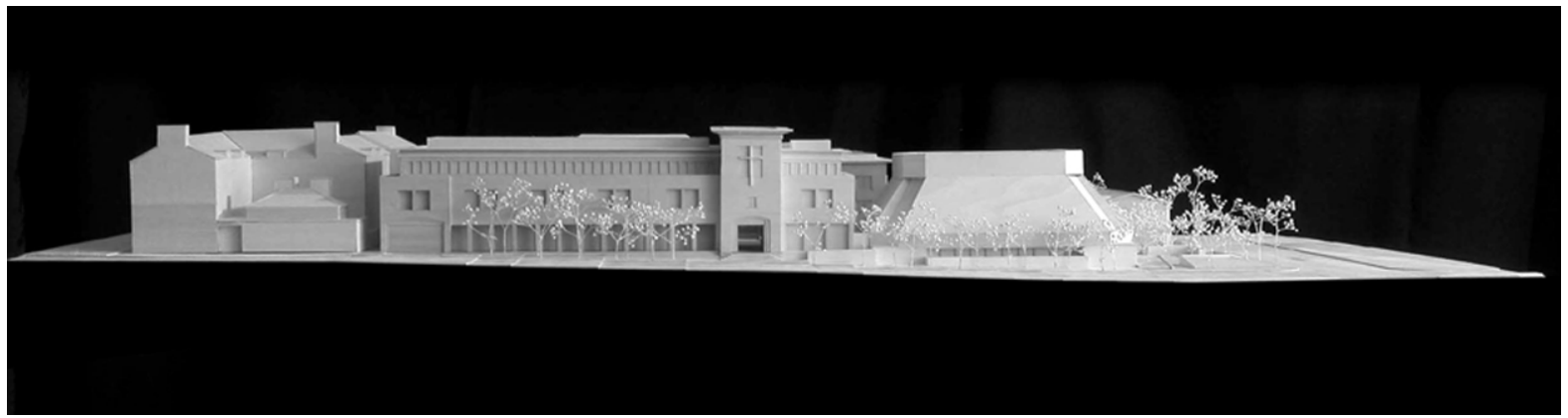

Figure 1. Channing Way Elevation, First Presbyterian Church of Berkeley Known as Geneva Hall, the new building (center in image above) respects the cornice line established by an existing University of California dormitory (left) and the church's existing sanctuary (right)

[model photo by Treve Johnson]

Throughout the redesign, communication with the neighborhood groups and the congregation was essential to ensure that all parties remained committed to the new direction. For the congregation, perhaps the most difficult part of the redesign was the renovation of the historic building. Many members were still bitter about the lawsuit and were unimpressed with the building's appearance. The 100-year old building was rather rundown and its backside faced the church property. To address this concern, the revised plan called for all new exterior materials to replace the deteriorated roofing and siding and, more significantly, the plan called for rotating the building 180 degrees so that its entry porch could face a new plaza on the church's property. For the preservationists, this rotation caused some displeasure. Some thought that if the church could rotate a historic building, then other owners of historic properties might want to do the same. But after numerous discussions, all parties agreed that rotating the building was in the best interest of the church and the building. Because of this collaborative process, where each party's goals were met in a way that still allowed for rather creative solutions, the three neighborhood groups that opposed the initial project wrote letters to the Zoning Board in favor of the revised plan. This support was essential. In the end, the congregation unanimously adopted the revised project and the Zoning Board unanimously approved the application. Construction commenced in the summer of 2003 and full occupancy occurred in 2006.

\section{EXPANDING THE CONCEPT OF "ENVIRONMENTAL" DESIGN}

\subsection{Uncovering the Project's Multiple Environments}

A building exists within a context that has no property lines. While needs of property owners must be accounted for, the owners must also realize that their projects have impacts beyond their property lines. These include visual, aesthetic, and environmental impacts. But if designers only consider the environment in its narrowest terms, in terms of energy use and material selection, they may run the risk of not getting anything built. In the public approval process for this project, these ideas carried little weight, even in a city as progressive as Berkeley. More important was the fit between the proposed project and its socio-cultural context.

If "green" is an environmental concept applicable to the design and construction of buildings and landscapes, then we should not limit the scope of the concept solely to the natural environment. Rather, we should include key "environments" in which designers operate, including the socio-cultural, political, and natural environments. In this project, the design team recognized that to be "green," the design must recognize the interrelationship between these multiple environments. 


\subsection{The Socio-Cultural Environment}

It is quite helpful for designers to consider the larger environments within which they are working. Focusing on one at the expense of another will result in an unbalanced and perhaps unbuildable project. The socio-cultural environment is perhaps the most challenging. It includes the system of relationships, rules, and cultural practices that govern the complex network of individuals, families, coworkers, neighbors, and members of the larger community (Anderson and Carter, 1990). This systems approach recognizes that, like buildings, people do not exist in isolation. Rather, they operate within an interdependent structure. This systems approach also applies to the buildings built by every culture. Amos Rapoport's (1992) concept of "cultural landscapes" is relevant here. Landscapes, which encompass the built and natural environments, respond to cultural values and express societal rules governing spatial priorities and development practices. In light of this, if culture can be defined in part as the evolving and shared beliefs, attitudes, and practices of a group, then that culture is reflected in the shape of the built environment. For the church, their initial proposal did not reflect their stated and practiced cultural position, which stressed community and connectedness. In attempting to demolish the McKinley Annex, the church ignored the desires of the larger community, which was clearly expressed through the listing of the building as an historic structure. In proposing a building that was completely isolated from its setting -surrounded by chain link fences and security walls - the church did not respond to its practice of integrating with and being open to the surrounding community. In ignoring the rules of the community and nonchalantly claiming these rules could be waived, the church set itself up for failure - failure to respect the results of the planning process in place in its chosen community.

In reworking the design, the first priority was to create a campus that respected the church's socio-cultural environment. Internally, this meant that the proposed construction respond to the needs and norms of the church membership. In practical terms, for example, this meant that adult classrooms be designed to accommodate a range of sizes that reflected generational differences in learning. The most senior members of the church met in large groups, Baby Boomers met in smaller seminar-like settings and members of "Generation X" wanted even smaller places where their tight-knit circles could meet and share the most private aspects of their lives. This also meant that the typical measures of building efficiency were largely irrelevant. An efficiency ratio of $70 \%$, for example, was not a measure of success considering that non-program spaces in religious education buildings are where important informal education and social bonding occurs. This meant that rather than program for two meter wide corridors, main corridors should be at least four meters wide and function like rooms in their own right, with places to sit and access to natural light. This also meant that there should be significant new open spaces that complemented the existing structure of patios and courtyards. The existing patio, for instance, functions as an outdoor lobby and meeting room and capitalizes on Berkeley's mild weather. These outdoor rooms add to the capacity and programmatic flexibility of the church. That the first design failed to provide such a space was surprising given that many of the staff and members of the church placed such a space near the top of their prioritized list of needs.

Externally, creating a campus that respected the socio-cultural environment meant that the proposed construction must, at a minimum, be what one building committee member called a "good neighbor." It should fit into its environment rather than stand out. Again, from a practical standpoint, this meant, for instance, that the building should maintain the street wall height and build-to lines of its neighbors. Also, the campus plan should in some way account for the mid-block pedestrian crossing that previously existed on the site. And the new building should provide protection for the area's homeless population in a way that allows for some dignity in where they sleep. In reconsidering the master plan for the church, the new concept design team also had to internalize the Senior Pastor's belief that, "Buildings are not that important. What matters is what they allow us to accomplish." But these accomplishments, from weekly meals and medical care for the area's homeless to subsidized preschool for the area's workforce, require space - and design matters in the making of this space.

\subsection{The Political Environment}

The making of this space is a political act. It requires making judgements about who gets the space, who pays for it, and who sets the rules for its design. In a place as contentious as Berkeley, this political environment can be an unknown environment for designers. As social scientist Diana DiNitto (1991: 7) argues, the political environment of policymaking "... arises out of the nature of the problems confronting society and over what, if anything should be done about them." If politics can be defined as who gets what, when, and how, (Lasswell, 1936) then architects are constantly operating within the political arena. Multiple competing perspectives often clash in the political arena. Unfortunately, architects are not well educated on the complexities and nuances of the political approval process. Rarely do studio instructors discuss the politics of design. Designers usually learn through on-the-job training, which is less than ideal. For First Presbyterian Church of Berkeley, the political environment was a particularly challenging one. In Berkeley, all development proposals are viewed with some disdain. And religious institutions receive extra scrutiny. At the same time the First Presbyterian Church was going through the planning process, another congregation in north Berkeley was trying to get their own plans approved. Their well-known architect ignored the stated concerns of the community and pressed forward with a 
controversial design that generated significant opposition. Neighborhood groups formed to block the project. Yard signs sprouted around the city urging denial of the congregation's permit application. After considerable delay, the project was approved by one commission then denied by another. The project ended up on appeal to the city council. At council direction, the parties went through several rounds of negotiations and redesign before a permit was finally issued. This was an outcome the design team and pastoral staff at First Presbyterian Church did not want. Fortunately, the collaborative process that brought First Presbyterian Church's political opponents into the design effort succeeded in creating a supportive political environment. There were no yard signs.

The political environment within the church was also a challenging one. Specifically, many members of the congregation did not want to spend any money on renovating the McKinley Annex. Several prominent members strenuously opposed removing a significant tree on the site, which was unfortunately in the way of construction. Other members wanted the budget devoted almost solely to building more parking. And there were members who simply could not justify spending so much money on construction when so many people around the world were in need of basic healthcare, food, and education. At one point, the Senior Pastor, Mark Labberton, reminded the design team that one main reason churches split is over construction projects. With dozens of committees and hundreds of constituents, this was a real possibility. Throughout the programming and design process, all of these constituents had to be heard, informed of the progress, and at times educated on the decision-making process and outcomes.

\subsection{The Natural Environment}

The natural environment is perhaps the easiest one to deal with in the design process. Architects are typically well educated in ways buildings should respond to climate and the environment. Moreover, many of the strategies employed by architects are not controversial and receive little notice. Numerous reference books exist that can guide the design process. In this case, G.Z. Brown's (2000) Sun, Wind, and Light was especially helpful. Deep overhangs that shade south elevations, recessed windows that block direct summer sun, narrow wings that allow light in on multiple sides, thick walls that accommodate ample insulation, and operable windows that support natural ventilation are common sense approaches to designing "green" buildings. For this project, the design team also benefited from the City of Berkeley's Green Building program, which provided peer evaluation of the design and a compliance report that noted the project's successful features and offered recommendations for improvements. The report noted, for example, that Berkeley's mild weather makes the area ideal for applying passive heating, cooling, and ventilation techniques Annually, the city has just 63 cooling degree days (cumulative number of degrees per year above $18.3^{\circ} \mathrm{C}$ ) and 1,612 heating degree days (below $18.3^{\circ} \mathrm{C}$ ).

\section{3. "GREEN" STRATEGIES}

\subsection{The First Imperative: Renovation}

Before considering other strategies, designers and owners should look to renovation as the first "green" imperative. If a building's lifecycle can be extended, then the environmental and economic costs associated with demolition and the production of new materials can be avoided. For First Presbyterian Church, the $819.2 \mathrm{sm}$ (8,818 sf) McKinley Annex (Fig. 2) and 5,253.3 sm (56,546 sf) Christian Education building were saved. Renovation of the former included bringing the old building up to California' strict energy, accessibility, and seismic standards. The only new building built as part of the project was Geneva Hall (Fig. 3).
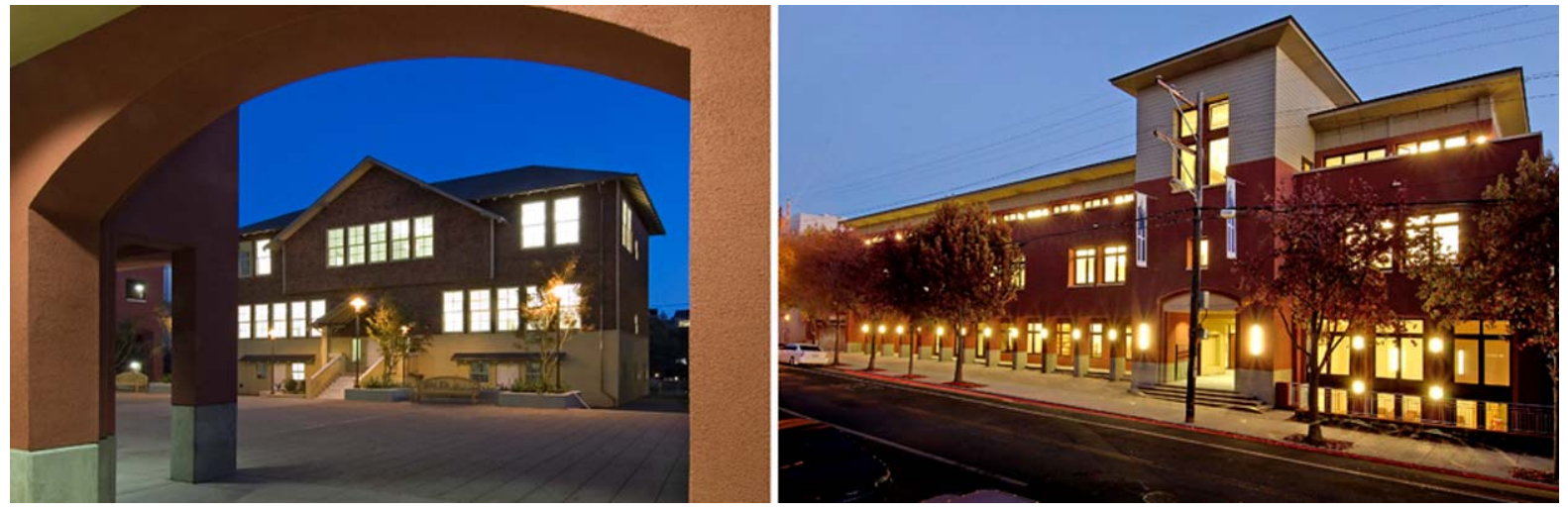

Figures 2 (I) and 3 (r). McKinley Annex (left) and the new Geneva Hall (right)

The renovated annex defines one edge of the new plaza. Geneva Hall continues the street wall along Channing Way and provides arcades and a clearly defined tower marking the public entry into the plaza. [photos by Treve Johnson] 
Surprisingly, the cost for renovation was even $20 \%$ less than new construction. Moreover, the church was able to get a remarkable building, with large windows and 4-meter high ceilings. Although many members of the church were reluctant supporters of renovating McKinley Annex, now that it is in use the benefits are clear. One occupant who did not want to move from her old windowless counselling rooms, now raves about her light filled offices and said, "We've been counselling all these years in the dark and didn't even realize it. Now we're in the light, physically and spiritually" (Hedlund, 2006).

\subsection{A Campus Approach to Green Design}

The existing campus had three buildings, a surface parking lot, a little used courtyard, and a rather attractive patio that fronted the sanctuary. Little tied the buildings together other than a few walkways. The disconnected nature of the campus led the church to think of the buildings in isolation. The members considered McKinley Annex worthless and a candidate for demolition. Some saw the existing sanctuary as a glass-walled jewel that should stand alone. In addition, the existing education building (Westminster Hall) was, according to the first architect, too old to efficiently bring up to current seismic standards. However, once the new concept design team showed a sketch that used a large new plaza to link the three existing buildings with the new education and administration building, many in the church began to see the value in creating a real campus - a place where buildings shape outdoor rooms, where walks are direct and comfortable, and where landscaping softens the edges (Fig 4). This led to a more integrated view of the individual buildings, which were now part of a whole ensemble. Rather then sit in isolation; the buildings could work together to create a walkable campus. In fact, all the buildings were needed to provide spatial definition to the campus. The widely supported plan (at least within the church) to demolish the McKinley Annex and Westminster Hall was taken off the table largely because of the campus approach to design.

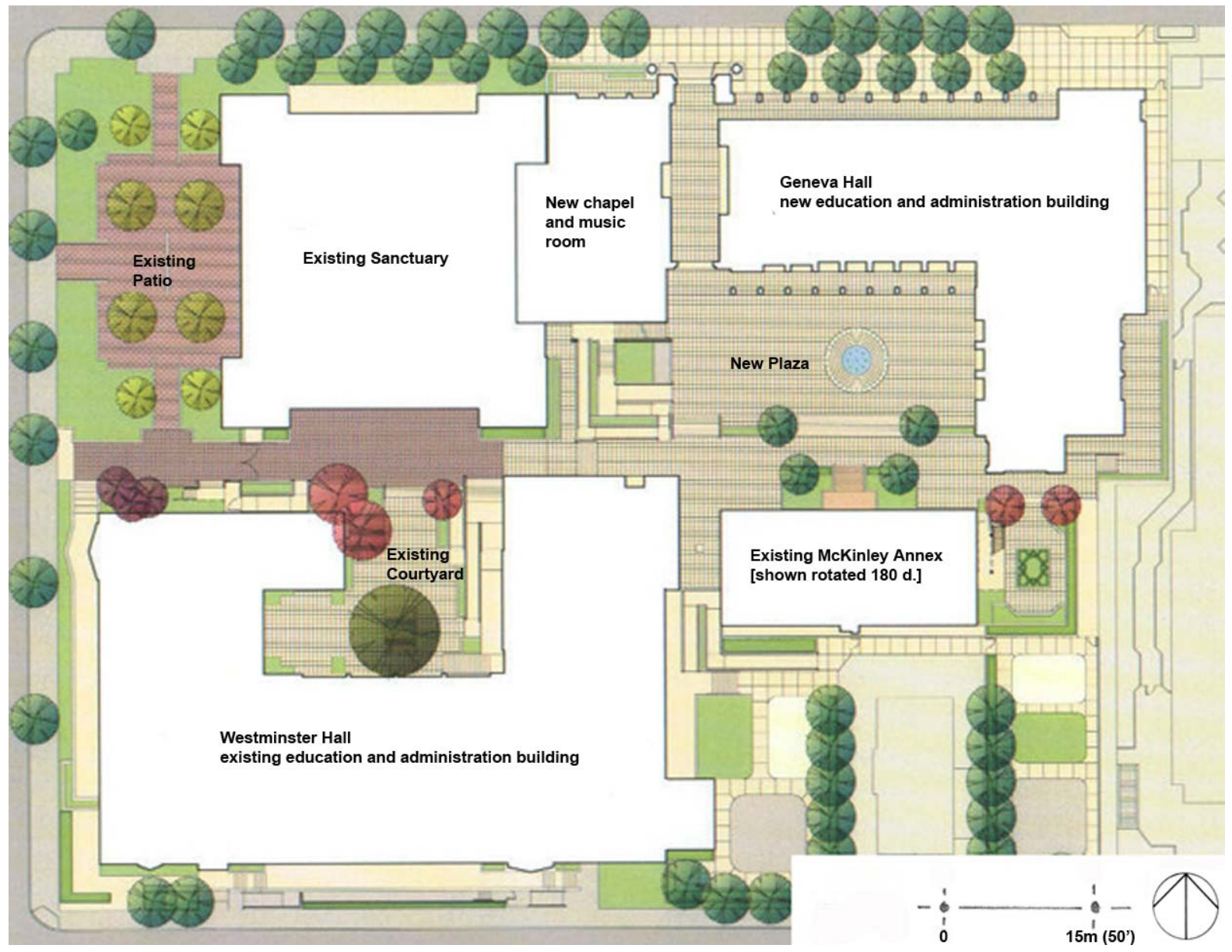

Figure 4. Campus Plan, First Presbyterian Church of Berkeley Geneva Hall's narrow wings and a renovated McKinley Annex help shape the new outdoor plaza. [image courtesy of First Presbyterian Church of Berkeley] 


\subsection{Greening the Buildings: A Simplified Approach}

For the individual buildings, rather than rely on complex active systems, the concept design team focused on providing layouts that benefit from passive strategies for lighting, heating, and cooling. The first move was to narrow the new building substantially from the original design. Rather than design a 30-meter wide building, the new standard was for what architect Chris Alexander (1977) calls 'Wings of Light.' While not as narrow as Alexander's pattern, at 18 meters the new building's wings and internal glazing allow light to enter almost every space from two sides (Figure 5). This has a positive environmental and emotional effect. The overall layout and use of operable windows allows for passive ventilation and eliminates the need for air-conditioning. Using natural ventilation "...improves air quality, ensures good ventilation and saves both energy and money," according to Leon Glicksman, director of MIT's Building Technology Program (cited in Stauffer 2006: 1). Moreover, according to Nancy Stauffer of MIT's Laboratory for Energy and the Environment, studies have shown that people generally feel more comfortable in a naturally ventilated building than in an air-conditioned one (Stauffer 2006). It is unfortunate that few commercial buildings rely on natural ventilation. Even in Berkeley, two recently completed buildings with similar functions (i.e. education and administration) were built with fixed windows and a reliance on air conditioning. Perhaps too few building owners can tolerate the trade-off -- a greater internal temperature swing. Admittedly, the temperate climate of Berkeley certainly helps. Nevertheless, occupants still experience daily temperature swings of up to 4 degrees Celsius. Surprisingly, there have been few complaints on the office floor or in the classrooms about indoor temperatures either being too hot or too cold. This can be attributed in part to the fact that the occupants never became accustomed to the more exact temperatures available with air conditioning and to the fact that they can open or close the windows as needed, which gives occupants an important sense of control over their environments. If the occupants can accept more fluctuation in the interior temperature, the environmental benefits are substantial. With its natural ventilation, daylighting, and passive heating, using conservative measures, the revised plan saves an estimated 94,000 kWh per year, which translates into an annual estimated CO2 emission reduction of 21,636 kilograms (47,700 pounds). This represents a $28 \%$ savings over the original plan. Over a 50 -year period, this equates to savings of nearly 4.7 million kWh and nearly 1.1 million kilograms of $\mathrm{CO} 2$ emissions.

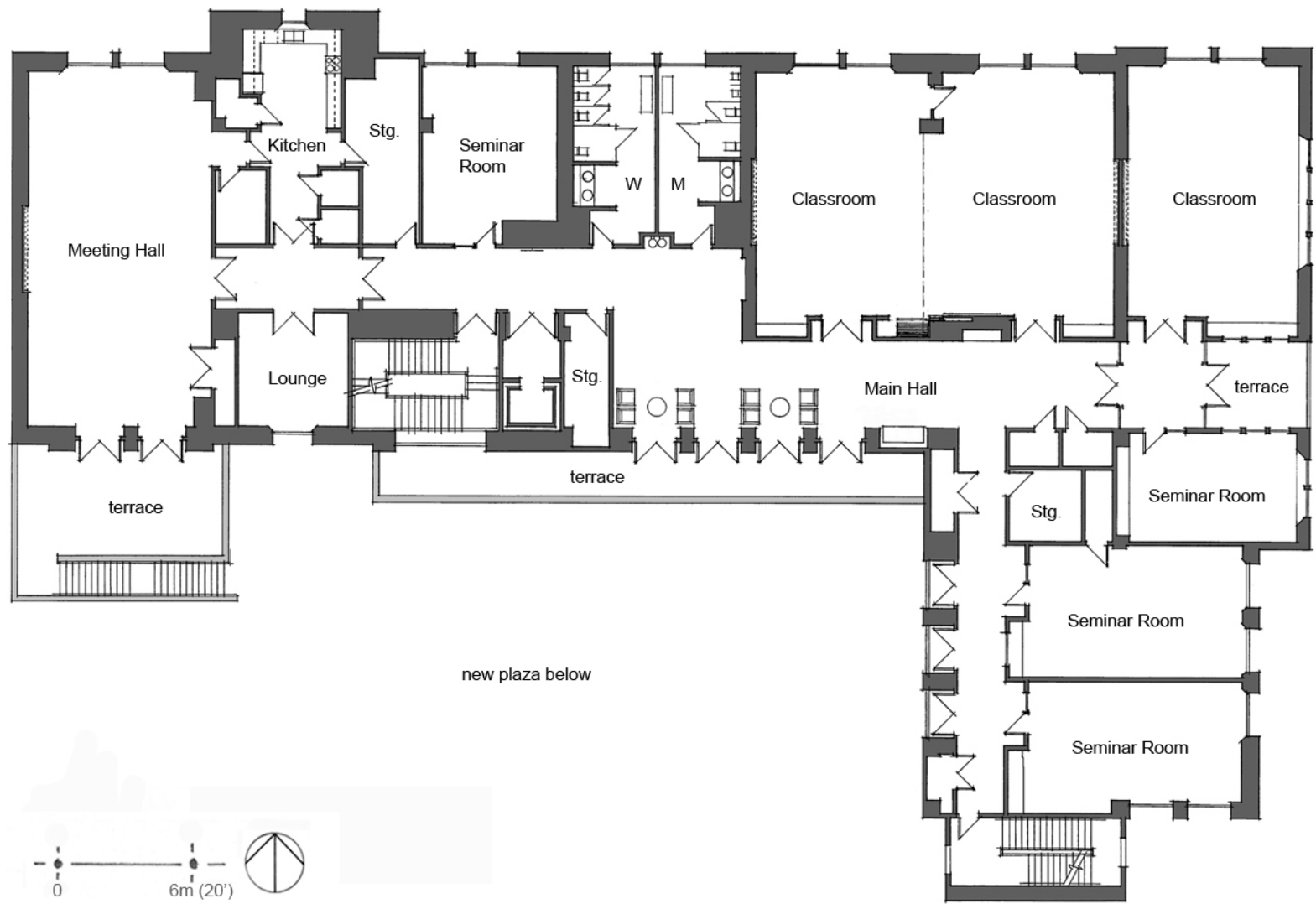

Figure 5. Second Floor Plan, Geneva Hall

The new building's narrow wings allow for light to enter two sides of every classroom, either directly through windows to the exterior, or indirectly through glass doors and sidelights. In addition, all occupied areas have windows, including the kitchen, stairways, corridors, and bathrooms. Small balconies and terraces on the south and west side connect the interior and exterior while shading the glazing below. 


\section{CONCLUSION}

In this project, two architects had a very different understanding of the project. The original designers focused on aesthetic issues, not on issues of sustainability. While they did an admirable job of responding to the client's program needs in terms of space, they failed to validate those requirements against the limited budget or the site's contextual constraints. What emerged was an unbuildable project. The new concept design team reframed the design and encouraged the client to think of issues beyond space and aesthetics. The client needed to recognize that their 'community' extended beyond their property lines and understand that the site could not accommodate all of their desires, which led to a reprioritization of needs. The role of the designer is not simply to make an aesthetically-pleasing building, which in any case is highly subjective, nor should the designer simply meet the client's identified space needs. Rather, designers should collaborate with their clients to create designs that respond to the budget, mission and context (physical, political, cultural, and environmental).

The conference organizers asked participants to consider, 'What are the top ten, most important design moves that students should know how to do in order to design carbon neutral buildings?' While not overly technical, this case study provides students examples of numerous 'design moves.' Specifically, students should:

1. learn how to reuse buildings whenever possible,

2. design buildings with narrow wings to capture light on multiple sides,

3. layout primary rooms so that they have incoming natural light from at least two sides,

4. allow for natural light to access nearly every space - including lobbies, hallways, and bathrooms,

5. provide operable windows to allow for natural ventilation and user control,

6. add thermal mass where possible to capture solar gain and reduce heating demand,

7. include deep overhangs, arcades, and recessed windows to block the high summer sun,

8. avoid air-conditioning, and, if possible, avoid forced air systems all together,

9. make buildings so comfortable and flexible that future owners will avoid demolition, and

10. learn to operate within the socio-cultural, political, and natural enviroments.

While these concepts are hardly original, the disappointing fact remains that even newer buildings supporting similar uses are being built in Berkeley and around the country without following any of these points. A series of ten points and a well-intentioned process, like the one used by the initial architects, will not, by themselves, lead to green buildings. Designers must respect the socio-cultural environment and engage with the political environment in order to produce buildings that minimize our impact on the natural environment.

\section{ACKNOWLEDGEMENTS}

This author was the Concept Architect and Project Manager for the project and would like to acknowledge the work of the final Architect - ELS, and the members of the First Presbyterian Church's Facilities Task Force and Architecture and Engineering Committee. The author would especially like to thank Paul Berry and Jim Childers.

\section{REFERENCES}

Alexander, Christopher, Sara Ishikawa, Murray Silverstein. 1977. A Pattern Language: Towns, Buildings, Construction. Oxford University Press: New York.

Anderson, Ralph and Irl Carter. 1990. Human Behavior and the Social Environment: A Social Systems Approach. Aldine de Gruyter: New York.

Brown, G.Z. and Mark Dekay. 2000. Sun, Wind and Light: Architectural Design Strategies, 2nd Edition. John Wiley and Sons: New York.

DiNitto, Diana. 1991. Social Welfare: Politics and Public Policy. Prentice Hall: Englewood Cliffs, New Jersey.

Hedlund, Sandi. 2006. Personal Interview.

Lasswell, Harold. 1936. Politics: Who Gets What, When, and How. Free Press: New York.

Rapoport, Amos. 1992. 'On Cultural Landscapes.' Traditional Dwellings and Settlements Review III, no. II: 33-47.

Stauffer, Nancy. 2006. Comforable Buildings, Hold the Air Conditioning. Laboratory for Energy and the Environment, Massachusetts Institute of Technology: Boston, MA. Available at http://web.mit.edu/newsoffice/2006/buildings.html [accessed January 3, 2007]. 